\author{
Lyudmila Levkovska \\ Doctor of Economics, \\ Public Institution "Institute of Environmental Economics and Sustainable Development \\ of the National Academy of Sciences of Ukraine", Kyiv, Ukraine \\ E-mail:levlv@ukr.net \\ ORCID: https://orcid.org/0000-0002-7823-7062

\section{Alla Omelchenko} \\ PhD in Economics, \\ Public Institution "Institute of Environmental Economics and Sustainable Development \\ of the National Academy of Sciences of Ukraine", Kyiv, Ukraine \\ E-mail: alla.omeltschenko@gmail.com \\ ORCID: https://orcid.org/0000-0001-8755-0889
}

\title{
Strategic guidelines for combating climate change and threats in global environmental security
}

\begin{abstract}
It is substantiated that the development of scientific and technological progress since the middle of the last century has led to intensive industrialization that, together with globalization processes, has resulted in global climate change. Nowadays, combating global warming is one of the most challenging and urgent tasks of humanity. Sweeping changes in natural systems, primarily an increase in the frequency and duration of droughts, floods, melting glaciers and rising water in the seven seas, biodiversity loss, etc., are the effect of global temperature rise. There is also a deterioration of living conditions and standards of the public, declining food security, especially in low- and middle-income countries. The research outlines the main trends in climate change. It is clarified the impact of climate change on the environment, man, society, and economy. The authors emphasize the significance and role of local actions towards adapting to the effects of climate change, which may become a tool for reducing climate risks in a global environment. It is justified that the challenge of climate change is addressed by joint efforts of each state of the world economic space. The effects of climate change and adaptation measures within economic realms are regarded by relying on global experience. The purpose of the article is to determine strategic guidelines for implementing adaptation measures to the impact of climate change to guarantee global environmental security. The research is based on a systems approach to solving the issue of guaranteeing global environmental security. In this context, it refers to the stimulation of constant economic modernization and the development of a new economic structure of the $21^{\text {st }}$ century aimed at searching for effective mechanisms and tools promoting the measures for reducing greenhouse gas emissions. First of all, this means the implementation of energysaving technologies, which will reduce the energy intensity of production and thus, increase economic energy efficiency and enhance global environmental security.
\end{abstract}

\section{Keywords}

Strategy, climate change, adaptation measures, environmental security, globalization, priority areas, modernization

JEL: F64, Q01, Q5

\begin{abstract}
1 Introduction
In the modern era, a new strategy of civilizational development requires synergies between progress and security. Moreover, guaranteeing the security of civilization is impossible without switching to sustainable development, as well as sustainable development (the purpose of which is to keep civilization and the entire biosphere safe) cannot be achieved without global security. In the current circumstances, efforts aimed at improving the security level of a particular security object (state, population, an individual, a business entity, etc.) should be concurrently focused on global security. In this regard, the priority areas towards reducing the impact of climate change on the biosphere become relevant, and the security principle, which prioritizes ensuring the security of a more comprehensive system than the security of individual elements of its components, comes into effect.
\end{abstract}

The states of America, Western Europe, and tropical and equatorial latitudes have countered the adverse effects of climate change for a long time. A good deal of analytical studies, short- and long-term regional and state programs, projects and forecasts, recommendations for combating climate change belong to the experts of the above regions. In particular, D. Barriopedro predicted climate change and reconstructed the climate of various regions of Europe using the data for the last 500 years, and W. Parry studied the frequency of heatwaves over 1500 years. The European project "Climate Change and Adaptation Strategies for Human Health" (cCASHh) (Umweltbundesamt) deserves attention. We have approached the concept which was announced at the 1992 Summit on Sustainable Development think globally, act locally; it of interest at this time. In other words, problems should be solved at the national and subnational levels. The challenge of climate change is addressed 
by joint efforts of each state of the world economic space. The main objective is to reduce the adverse effects of global warming. To achieve this objective, one has to guarantee appropriate conditions at the local level, i.e., to act "from the bottom up". As the switch to sustainable development is possible only on a global scale and in a coherent order of all security facilities (and entities as well), any decisions and actions on ensuring the security of any facility should not contradict the international imperatives of sustainable development. All this points to the systemic nature of ensuring global security through sustainable development because global, regional, national, and local aspects are combined into one systemic unit but based on planetary imperatives. The world is facing and will continue to face some challenges caused by climate change. In an effort to address these challenges and prepare for future changes, countries are developing and implementing measures for adaptation to climate change.

\section{Statement of the basic material}

The Intergovernmental Panel on Climate Change (IPCC) considers adaptation to climate change as an adjustment in natural or human systems and a response to actual or potential climate impacts or their implications that can reduce their harm or take advantage of favorable opportunities. Thus, it was established four groups of measures which address various aspects of the manifestation of climate change and their impact on natural and socioeconomic systems and focus on:

- building adaptation capacity - understanding and awareness of the existence of the climate change process, its implications, and thus, response to these changes (e.g., study of the manifestation of climate change, its impact on the population and economy, elaboration of disaster plans and response protocols, floodplain maps, etc.);

- risk and sensitivity mitigation - the development and implementation of measures to increase resilience and protection against short-, medium- and long-term climate change (e. g., cultivation of new crop varieties instead of traditional ones, seawalls along coastal reservoirs, early warning systems, etc.);

- capacity improvement for emergency response development, planning, and implementation of measures to mitigate implications and restrain natural disasters that have already taken place (e.g., provision of facilities for cooling during heat, creation, and replenishment of a special fund in case of emergencies (fires, floods), emergency services);

- deriving profit from transformed climatic conditions (e.g., the benefit of longer growing seasons of new crop varieties due to warming).

\section{Climate change impacts on urban areas}

Climate change impacts in large and small cities, the concentration of powerful industrial enterprises, and emissions of air pollutants from transport have a drastic effect on the health of locals. Previous studies have shown that many countries had been working for a long time to implement a strategy for minimizing climate change impact on urban areas, as the lion's share of the population lives in urban areas. Most of the measures related to urban life concern the heat, namely, the reduction of its effects on the population. Other possible measures concern floods and water resources during or after emergencies (Erik). Among them, one marks the following key areas:

- a mandatory requirement to assess vulnerability to the effects of climate change and adaptation to amendments made in urban and municipal plans;

- development of new standards and their observance during the construction of new buildings (for example, collection and use of rainwater, more efficient use of natural light), as well as improvement of the regulatory framework on planning and construction (new design standards for overheat protection (building orientation, retrofitting existing buildings with green roofs for better insulation during heat and cold and water retention, "greening" of walls and fences for shading, use of light materials for external walls that will reflect more heat));

- identification of housing boundaries to maintain sufficient fresh air as well as the determination of requirements for building height and the number of stories, avoidance of buildings' overdensity to mitigate emergency consequences;

- renewal of the municipal sewer system to take a large amount of water during heavy rains, and the development of the plan of actions in such situations;

- - development of measures for structural protection of buildings from extreme heat: thermal insulation, sun protection using external blinds and windows, ventilation systems;

- extension of green areas in places where urban heat is felt most;

- creation of a more efficient ventilation system for urban underground transport.

According to the latest researches, the effects of global warming in urban areas are felt several times stronger than in rural areas. Cities, which occupy about $1 \%$ of the land area, are now home to half of the world's population and, at the same time, they produce $80 \%$ of global GDP and consume $78 \%$ of energy (Francisco Estrada,). According to the pessimistic forecast, urban economic losses from warming could reach $10.9 \%$ of GDP by the end of the century compared to the global average of $5.6 \%$. In the authors' opinion, the impact at the urban level is no less important than at the global level. It is proposed to consider the transition to constructing sidewalks and roofs made of materials that reflect more heat than current ones as a means of prevention. By relying on estimates, the replacement of $20 \%$ of roofs and $50 \%$ of sidewalks with the latest counterparts will help mitigate urban air temperature by 0.8 degrees. Previous studies have shown that many countries have long been working to develop and implement strategies for mitigating climate change impact on urban areas, i.e., construction and designing buildings with due regard for future climate change, prioritizing energy savings, traffic reduction by restricting traffic in particular city districts, the creation of information systems on urban climate to keep the population informed, etc.

For instance, in Ukraine, the development of a national climate and adaptation strategy is currently at an early stage. However, some cities (Plan zakhodiv $\mathrm{z}$ adaptatsii hromady mista Kam'ianske do naslidkiv zminy klimatu) have already worked out relevant pilot projects. Nowadays, city leaders must work towards developing adaptation programs and their immediate implementation. According to data 
provided by the international organization 350.org, the main manifestations of climate change primarily comprise financial losses and discomfort for the population. Keeping in mind the current rate of warming, weather anomalies will trigger by human losses. However, it should be emphasized that within different regions of both the world and one country, climate change has a different, sometimes opposite, manifestation - desertification or waterlogging. Therefore, landscape features and local environmental concerns should be taken into account and become a pillar when developing adaptation measures. The space of agglomerations has its own microclimate. In addition to the air temperature, which is higher than in uninhabited areas, more intense cloud cover and precipitation are formed above the city. In this context, the real challenge to all cities is the emergence of prolonged and heavy rains, and the sewer system built under other conditions doesn't manage to cope with significant amounts of rainwater. Therefore, the so-called "sustainable landscapes", which are created under the principles of ecological balance, viability and maximum self-sufficiency, can help cities adapt to such conditions. About 20 years ago, developed countries of Western Europe and North America began to advance decentralized treatment systems, which provide for immediate conveying and treatment of rainwater in neighborhoods and on the streets and are artificial biodrainage systems. Outwardly, they look like ordinary flower beds but with specific plant species which are resistant to both waterlogging and lack of moisture. The surface of the flower bed is composed of soil mixtures that are well permeable to rainwater. The soil, together with the roots, serves as a natural filter for water. The municipalities of such cities as Berlin, Portland, and New York have already developed and partially implemented urban, street, and public space redevelopment programs. In Ukraine, the design of sustainable landscapes is at an early stage (Ferendovych). In 2020, the Austrian capital carried out a range of special measures specified in the "City Cooling Program". Asphalt is replaced with other material on one of the main streets of Vienna. The municipality is struggling against heat islands in that way. The document consolidates the following: the reconstruction of infrastructure facilities with an emphasis on the replacement of impermeable surfaces, reasonable use of water as an element of design and cooling, additional funding of vertical and facade landscaping projects, large-scale tree planting campaign, creation of additional shading sources, installation of new pump rooms with drinking water, wide bicycle parking lots, the introduction of "green" standards for new buildings. A set of such measures should mitigate the vulnerability of city residents to the abnormal heat expected in the summer.

In addition to the reconstruction of streets, the design of green roofs and facades of buildings becomes a promising direction for addressing the challenges of climate change adaptation in urban agglomerations. The new suburbs of Paris are designed in a way that meets the conditions of sustainable development and relies on the principles of interaction between society and nature, environmental protection, and efficient use of natural resources. For instance, one of the new city districts was built using a series of innovative solutions: hot water is supplied to buildings not from the boiler house, but underground geothermal sources. Thus, two wells were purposely drilled under the housing complex.

\section{Climate-related risks for economic performance}

According to experts, the main risks of climate transformation encompass an increase of natural disasters (especially hydrometeorological), irreversible loss of water, land, and forest resources, changes in the ecosystem of living organisms, and thus, the loss of biodiversity. Scientists have identified human activity since the middle of the twentieth century, i.e., intensive industrialization, as the root cause of global warming. Therefore, the Intergovernmental Panel on Climate Change has drafted a special report on the impact of global warming and its greenhouse gas emissions (Special Report Global Warming of $1.5^{\circ} \mathrm{C}$ ). The key conclusion is that warming will reduce the complex effects on ecosystems, human health and wellbeing only by $1.5^{\circ} \mathrm{C}$, and temperature increase by $2^{\circ} \mathrm{C}$ will exacerbate the manifestations of extreme weather and the processes of rising water of the global sea and, consequently, the reduction of Arctic water ice, coral bleaching and the loss of ecosystems in general. However, the rise of global temperature by $1.5^{\circ} \mathrm{C}$ is possible under reducing greenhouse gas emissions and changing behavioral models and technologies in all spheres of society, coordinating joint efforts aimed at achieving sustainable development and eradicating poverty. The mentioned group also published a report on the ocean and cryosphere in that environment (Special Report on the Ocean and Cryosphere in a Changing Climate), which revealed their impact on mountainous areas, polar regions, sea level rise, and effects for islands, coasts below sea level, ocean, marine ecosystems.

Most experts associate global climate change with serious risks for the world. The rapid growth of greenhouse gas emissions is causing complex transformations in the natural environment, including extreme natural events.

Numerous studies show that climate change has the maximal impact on the productivity of economic sectors that depend on fossil resources, the state and functions of ecosystems, the availability of water resources, and weather conditions. First of all, it is a case of the mining, fishing and food industries, agriculture, forestry and water management, recreation, and tourism. Climate change phenomena and the strengthening of the relevant countermeasures also cause powerful technical and structural shifts in various energy sectors (especially in the fuel industry), infrastructure (especially in the transport industry), mechanical engineering and metalworking, chemical industry, which, in turn, significantly intensify and increase financial flows in the insurance field (Sidenko, Veklych, 2016). The macroeconomic consequences of climate change impact will be manifested as a decrease in economic growth and the emergence of inflation processes. Damage caused by extreme weather conditions and natural disasters, mass migration, reduced security levels - all of these things can lead to a slackening of economic growth. Droughts and desertification will cause a decrease in agricultural production, a further decline in real income of the population and, as a result, an increase in food prices.

One can emphasize the following among the sociopolitical risks of global warming:

- migration and humanitarian problems due to the fact that a particular part of the inhabited territories has become uninhabitable;

- increased food prices and shortages, which will be primarily felt by the poorest social groups;

- social implications of natural disasters and their overcoming, etc. 
As detailed above, the introduction of energy-saving technologies in the industry to cut the energy intensity of production will help reduce greenhouse gas emissions, which is the main effective measure in the functioning of organizational and economic mechanism for preventing climate change impacts.

\section{Adaptation measures for climate change impact on economic sectors}

Different economic sectors and regions of the world are characterized by varying degrees of vulnerability to climate change. Agriculture, forestry, water sectors, and the energy industry may become the most vulnerable to climate change.
On a nationwide scale, the role of the government in avoiding contradictions between different industries during the development of adaptation measures to climate change, the determination of a coordinated cross-sectoral approach is of importance (EU framework for adaptation to climate change...). The UNDP "Adaptation Policy Frameworks (APF) for Climate Change: Developing Strategies, Policies and Measures" is a system guide for the development of national adaptation strategies (Adaptation Policy Frameworks for Climate Change - Developing Strategies...).

\section{Conclusions}

It is necessary to draw attention to the impact of climate change on different regions within the country

TABLE Climate change impacts and adaptation measures for economic sectors

\begin{tabular}{|c|c|c|}
\hline Economic sector & Climate change impacts & Priority adaptation measures \\
\hline $\begin{array}{l}\text { Agriculture and forestry, } \\
\text { land resources }\end{array}$ & $\begin{array}{l}\text { - temperature rise by } 2^{\circ} \mathrm{C} \text { without adaptation by the regions with } \\
\text { tropical and moderate climate will negatively affect yields of wheat, } \\
\text { corn, soybeans, rice; by } 4^{\circ} \mathrm{C} \text { - will cause the reduction of water } \\
\text { resources and increasing competition, which will weaken food security } \\
\text { globally; } \\
\text { - rise in temperature, uneven distribution of precipitation during } \\
\text { the year, inefficient accumulation of moisture in the soil can cause } \\
\text { the expansion of the risky agriculture zone, and in some areas - } \\
\text { desertification; } \\
\text { - change in the structure and volume of cultivation of dominant, } \\
\text { traditional for a particular region, crops; } \\
\text { - modification of natural zones' borders; } \\
\text { - being affected by increasing extreme temperatures in summer, the } \\
\text { species composition will change (extinction of some species and the } \\
\text { emergence of new ones, including invasive species) and the reduction } \\
\text { of forest areas; } \\
\text { - increasing temperatures in winter may moderate climate and } \\
\text { expand a range of some species of pests; } \\
\text { - due to warming impact, there is a change in the regime, intensity, } \\
\text { and frequency of precipitation that causes deterioration of the } \\
\text { sanitary state of forests, first of all, mass drying of stands and } \\
\text { increasing fire risk in dry and hot periods; } \\
\text { - anthropogenic deforestation exacerbates the devastating effects of } \\
\text { climate change }\end{array}$ & $\begin{array}{l}\text { To reduce greenhouse gas emissions - } \\
\text { modernization of existing models of agricultural } \\
\text { production and improvement of the agriculture } \\
\text { management system; } \\
\text { application of resource-efficient agriculture, } \\
\text { agroforestry, integrated pest control. }\end{array}$ \\
\hline Water resources & $\begin{array}{l}\text { - reduction of minor and medium rivers' flows, decrease of infiltration } \\
\text { recharge of groundwater, which will trigger a high probability of } \\
\text { insufficient moisture in arable land; } \\
\text { - further reduction of usable surface and underground resources }\end{array}$ & $\begin{array}{l}\text { Integrated water resources management based } \\
\text { on the basin principle }\end{array}$ \\
\hline Energy industry & $\begin{array}{l}\text { - decline in the general thermal efficiency of thermal power stations } \\
\text { (TPSs) due to increase of average annual temperatures and heating } \\
\text { and drying of the adjoining cooling reservoirs; } \\
\text { - the resource base of wind power plants (WPPs) is also strongly } \\
\text { influenced by temperature changes; } \\
\text { - climate change impact on nuclear energy is limited to low casualties } \\
\text { of thermal efficiency, as well as heating and drying of cooling } \\
\text { reservoirs. }\end{array}$ & $\begin{array}{l}\text { Use of process water (closed loop process water } \\
\text { recycling system) or more expensive dry cooling } \\
\text { technologies; } \\
\text { Increase of the amount of renewable energy in } \\
\text { terms of decarbonization of electric systems. } \\
\text { Advancement of wind resource estimation } \\
\text { techniques. } \\
\text { Accounting for random changes in energy } \\
\text { planning and the determination of sufficient } \\
\text { reserve capacity. }\end{array}$ \\
\hline Manufacturing industry & $\begin{array}{l}\text { - Direct influence (change of the framework of energy consumption } \\
\text { and availability of natural resources, increase in the risk of human- } \\
\text { driven emergencies, an insufficient amount of water resources of } \\
\text { adequate quality, etc.) and indirect influence (changes that occur in } \\
\text { related industries and involve modifying the economic conditions } \\
\text { of operation due to the dependence of processing enterprises on } \\
\text { agriculture and forestry management). } \\
\text { - Vulnerability of industrial enterprises and infrastructure facilities to } \\
\text { soil erosion, floods, sea-level rise, and related wave regime changes }\end{array}$ & $\begin{array}{l}\text { To ensure the sustainability of industrial } \\
\text { facilities, it is necessary to create registers } \\
\text { of strategic infrastructures and assess their } \\
\text { vulnerability to climate change. } \\
\text { Adaptation issues should be covered in overhaul } \\
\text { and reconstruction programs, investment } \\
\text { activities, project planning of expansion and } \\
\text { creation of new industries. }\end{array}$ \\
\hline
\end{tabular}

Source: compiled by the authors using the data provided by (Ivaniuta, Kolomiiets, Malynovska, Yakushenko, 2020) 
to manage the adaptation process effectively. Socioeconomic development priorities of some regions may differ and, in some cases, even contradict the priorities of neighboring ones. This requires effective coordination between regions. The challenge of climate change is addressed by joint efforts of each state of the world economic space. Mitigation of the adverse effects of climate change is a priority. It is essential to guarantee appropriate conditions at the local level, i.e., to act "from the bottom up", to achieve this goal. Therefore, moderation of global temperature increase is possible under reducing greenhouse gas emissions and changing behavioral models and technologies in all spheres of society, coordinating joint efforts focused on achieving sustainable development and eradicating poverty. As the popular majority live and work in cities, urban areas are most affected by climate change. Thus, it is crucial to develop a climate change adaptation strategy at the local level, which touches on the particularities of such changes in a particular region. To resist climate change and prevent its impact, the state must stimulate constant economic modernization and development of a new economic structure of the $21^{\text {st }}$ century based on a systems approach. It refers to the level of economic advancement of the country with an entirely new economic structure aimed at searching for effective mechanisms and tools contributing to the decrease of greenhouse gas emissions, primarily, the introduction of energy-saving technologies, reduction of energy intensity of production that will improve economic energy efficiency at the local and regional levels, on the one hand, and, on the other hand, contribute to a significant reduction in greenhouse gas emissions and boost environmental safety at the global level.

\section{References}

[1] Umweltbundesamt (2015). cCASHh - Climate Change and Adaptation Strategies for Human Health in Europe. E-source: https://www.umweltbundesamt.de/themen/klimaenergie/klimafolgen-anpassung/werkzeuge-der-anpassung/ projektkatalog/ccashh-climate-change-adaptation-strategies-for

[2] Erik E. Massei. Dosvid Yevropeiskoho Soiuzu v adaptatsii do zminy klimatu ta zastosuvannia yoho v Ukraini [The experience of the European Union in adapting to climate change and its application in Ukraine]. E-source: https://www.osce.org/uk/ukraine/104020?download=true (in Ukrainian)

[3] Francisco Estrada, W. J. Wouter Botzen \& Richard S. J. Tol. (2017). A global economic assessment of city policies to reduce climate change impacts / Nature Climate Change. Volume 7, pp. 403-406.

[4] Plan zakhodiv $\mathrm{z}$ adaptatsii hromady mista Kam'ianske do naslidkiv zminy klimatu [Action plan for adaptation of the community of Kamyanske to the consequences of climate change]. E-source: https:/climateforumeast.org/uploads/ files/__final_1.pdf (in Ukrainian)

[5] Ferendovych Yu. Stali landshafty yak umova vyzhyvannia mista [Ferendovych Yu. Stali landshafty yak umova vyzhyvannia mista]. E-source: https://pragmatika.media/stali-landshafti-jak-umova-vizhivannja-mista/ (in Ukrainian)

[6] Special Report Global Warming of $1.5^{\circ} \mathrm{C}$. E-source: https://www.ipcc.ch/sr15/

[7] Special Report on the Ocean and Cryosphere in a Changing Climate. E-source: https://www.ipcc.ch/srocc/

[8] Oliinyk, Ya. B., Stepanenko, A. V. \& Obykhod, H. O. (2011). Bezpeka zhyttiediialnosti naselennia pry ekstremalnykh temperaturakh za umov hlobalnykh zmin klimatu [Bezpeka zhyttiediialnosti naselennia pry ekstremalnykh temperaturakh za umov hlobalnykh zmin klimatu]. Kyiv. (in Ukrainian)

[9] Sidenko, V. R., \& Veklych, O. O. u.a. (2016). Ukraina i polityka protydii zmini klimatu: ekonomichnyi aspekt [Ukraine and the policy of combating climate change: economic aspect]. Kyiv: Zapovit. (in Ukrainian)

[10] Ivaniuta, S. P., Kolomiiets, O. O., Malynovska, O. A. \& Yakushenko, L. M. (2020). Zmina klimatu: naslidky ta zakhody adaptatsii: analit. dopovid [Climate change: consequences and adaptation measures: analyte. report]. Kyiv: NISD. (in Ukrainian)

[11] EU framework for adaptation to climate change, leading to a comprehensive EU adaptation strategy by 2013. E-source: https://www.eea.europa.eu/policy-documents/white-paper-adapting-to-climate

[12] Adaptation Policy Frameworks for Climate Change - Developing Strategies, Policies and Measures. E-source: https://www.adaptation-undp.org/resources/training-tools/adaptation-policy-frameworks 